\title{
Effects of Water Level Fluctuations on the Growth Characteristics and Community Succession of Submerged Macrophytes: A Case Study of Yilong Lake, China
}

\author{
Fengbin Zhao ${ }^{1,+}$, Xin Fang ${ }^{2, *,+}\left(\mathbb{C}\right.$, Zeyu Zhao $^{3}$ and Xiaoli Chai ${ }^{1}$ \\ 1 State Key Laboratory of Pollution Control and Resource Reuse, College of Environmental Science and \\ Engineering, Tongji University, Shanghai 200092, China; fbzhao@tongji.edu.cn (F.Z.); \\ xlchai@tongii.edu.cn (X.C.) \\ 2 School of Business, Macau University of Science and Technology, Macau 999078, China \\ 3 School of Economics and Management, Tongji University, Shanghai 200092, China; zhaozeyu@tongi.edu.cn \\ * Correspondence: xfang@must.edu.mo; Tel.: +853-663-31799 \\ + Equal contribution.
}

Citation: Zhao, F.; Fang, X.; Zhao, Z.; Chai, X. Effects of Water Level

Fluctuations on the Growth

Characteristics and Community Succession of Submerged Macrophytes: A Case Study of Yilong Lake, China. Water 2021, 13, 2900. https: / / doi.org/10.3390/w13202900

Academic Editor: Christophe Piscart

Received: 13 September 2021

Accepted: 11 October 2021

Published: 15 October 2021

Publisher's Note: MDPI stays neutral with regard to jurisdictional claims in published maps and institutional affiliations.

Copyright: (c) 2021 by the authors Licensee MDPI, Basel, Switzerland. This article is an open access article distributed under the terms and conditions of the Creative Commons Attribution (CC BY) license (https:// creativecommons.org/licenses/by/ $4.0 /)$.

\begin{abstract}
Water level fluctuation (WLF) has a significant effect on aquatic macrophytes, but few experimental studies have examined the effect of WLF on submerged community succession, especially from a large-scale perspective. In this study, field monitoring of WLF and submerged macrophytes was conducted in Yilong Lake (SE China) over two years, and the impacts of WLF on the growth characteristics and the community structure of submerged macrophytes were determined. The results show that the biomass of submerged macrophytes decreased significantly after the water level increased and submerged macrophytes could cope with the adverse environment by adjusting their growth posture, for example, increasing plant length and reducing branch number. However, different submerged plants have different regulatory abilities, which leads to a change in the community structure. Myriophyllum spicatum, Stuckenia pectinata, and Najas marina had better adaptation abilities to WLF than Najas minor and Utricularia vulgaris. Changes in water depth, dissolved oxygen, and transparency significantly contribute to the effect of WLF on submerged plant communities. Therefore, when determining the range of WLF, the above three critical factors and submerged plant species should be considered. WLF changed the spatial distribution of the aquatic plant community. When water levels rose, the density of the submerged macrophyte community in the original growth region reduced as the emergent plants migrated to shallower water, and the seed bank germination was aided by transparent water produced among emergent plants. This can be used as a pioneering measure to restore submerged plants in eutrophic lakes with low transparency. In addition, a suitable water depth created by WLF was conducive to activating the seed bank and improving the diversity of aquatic plants. Finally, a distribution map of aquatic plants in Yilong Lake is drawn.
\end{abstract}

Keywords: water level fluctuation; submerged macrophytes; growth characteristics; community succession

\section{Introduction}

Disturbance is a common event in nature [1]. Many studies have shown that moderate disturbance is conducive to maintaining species diversity, plant growth, and community productivity [2,3]. However, when the intensity of disturbance exceeds a certain threshold, the plant community is frequently harmed [4]. In recent years, due to the deterioration of climate conditions, the increasing frequency of drought and flood, and aggravation of the impact of anthropogenic activities, more than conventional-scale disturbances occur frequently [5] and have a strong impact on terrestrial and aquatic plants. A number of scholars have studied the effects of these disturbances on plant communities and individual plants [5-7]. Some scholars have also studied the impact of hydrodynamics and other 
factors on the ecosystem [8], but little attention has been paid to the impact of water level fluctuation (WLF) on the aquatic ecosystem. The aquatic ecosystem is unlikely to experience severe conditions such as direct drought and flood, while WLF has significant influences on the growth and community remodeling of aquatic plants [9]. Water level has been proven in numerous studies to have a major impact on submerged macrophytes and floating-leaved plants $[10,11]$, and WLF has direct or indirect effects on the growth and physiological characteristics of submerged macrophytes. For instance, scholars explored the response of plant height, fresh weight, root length, and enzyme activity of submerged macrophytes to WLF $[10,12,13]$. However, previous studies were mainly focus on small-scale water level simulation experiments, and very few experimental studies have examined the effect of WLF on the community structure of submerged macrophytes on a large scale, especially the effect of WLF on the community structure of specific submerged macrophytes in plateau lakes. Currently, WLFs driven by climate change are becoming increasingly common [14], particularly in plateau lakes with water shortages, and increasingly artificial, remote water replenishment measures are needed to ensure normal water levels in lakes. However, due to the short-term and sudden WLF caused by water replenishment, sufficient research data on the effect of submerged macrophyte communities in the whole lake are lacking.

This study is expected to provide references for the protection of submerged macrophytes in large-scale freshwater lakes. Furthermore, since WLF is a common hydrological characteristic of rivers and lakes [15], its amplitude variation, frequency, and duration affect the community stability and the composition of aquatic plant species [16]. Aquatic plants gradually adjust to periodic WLF over time as part of the long-term process of species evolution [17] and adopt their growth characteristics and community distribution periodically to respond to WLF, whereas non-periodic WLF frequently inhibits aquatic plant growth and reproduction. WLF directly affects the growth and reproduction of aquatic plants or indirectly affects aquatic plants by changing transparency, nutrients, gases, and other environmental factors [18]. Thus, WLF is one of the main environmental factors affecting the aquatic plant community. Studies have also shown that the degradation of aquatic plants is closely related to water eutrophication [19], water ecosystem imbalance, excessive human intervention, and water depth gradient $[20,21]$. However, WLF is a complex process that changes an aquatic plant's growth conditions by changing water depth, underwater irradiance, water quality, and dissolved oxygen conditions [22]. Therefore, compared with the study of small-scale environmental factors, exploring the effect of WLF on a submerged macrophyte community in a whole lake is more beneficial to the formulation of submerged macrophyte protection strategies.

To study the response characteristics of submerged plants to WLF, the growth characteristics of submerged macrophytes, including plant length, biomass, coverage, and branch number, were monitored during high and low water levels. Meanwhile, to assess the succession of aquatic plant communities under WLF, we monitored the community distribution of submerged macrophytes and emergent plants in two periods. The main objectives of this study are: (1) to determine the characteristics and potential mechanism of the effect of WLF on submerged macrophytes on a larger scale in Yilong Lake in SE China; (2) based on mastering the characteristics of the effect of WLF, to formulate a protection strategy of aquatic macrophytes based on water level management; and (3) to help us understand better the current situation of the aquatic plant system in Yilong Lake and make up for the lack of research data since 1980 (no systematic statistical data from research on submerged plants in Yilong Lake exist from 1980 to 2013).

\section{Materials and Methods}

\subsection{Introduction to Yilong Lake}

Yilong Lake $\left(102^{\circ} 31^{\prime} 5.23^{\prime \prime}, 23^{\circ} 42^{\prime} 5.56^{\prime \prime}\right.$, the water area: $\left.39 \mathrm{~km}^{2}\right)$ is one of the nine plateau lakes in Yunnan Province, China. Yilong Lake is a famous grass-type lake in its original state, with Vallisneria natans and Ottelia acuminata as the dominant submerged macrophytes. In recent years, with the continuous accumulation of pollutants around 
the lake and the continuous decline in water level, the submerged macrophytes have declined within a large area, and the dominant community of submerged macrophytes has also fluctuated significantly, with Stuckenia pectinata and Myriophyllum spicatum becoming dominant species. At present, Yilong Lake is shifting from a grass lake to an algal lake, and the water environment conditions of the East and West Lakes are quite different. (Yilong Lake is divided into eastern and western parts by a raised lake bottom in the center. For the convenience of description, this paper calls them the East Lake and the West Lake.) According to historical statistics, Yilong Lake's water level remained stable between 2000 and 2009. However, the water level has declined, due to overuse for agricultural water and reduced rainfall since 2010. In August 2013, the water level dropped to the lowest level in 15 years $\left(1410.50 \mathrm{~m}\right.$ ), and the water area was severely reduced (from $30 \mathrm{~km}^{2}$ to $16 \mathrm{~km}^{2}$ ). In June 2014, the Yilong Lake administration used remote water replenishment to elevate the lake level to $1412.00 \mathrm{~m}$ (Figure 1).

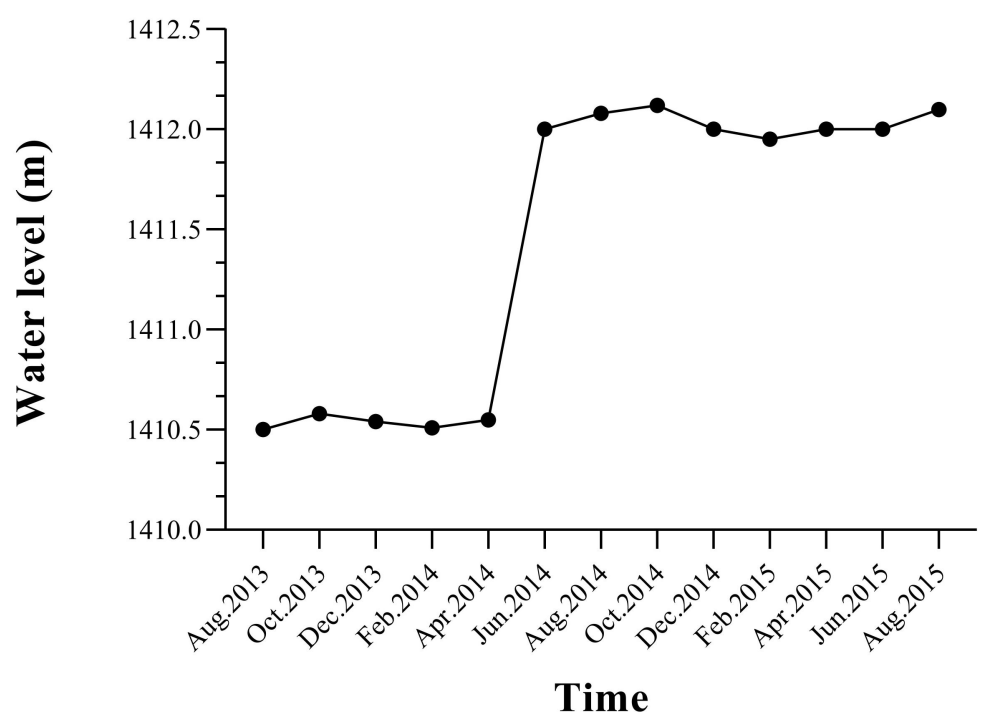

Figure 1. Time-course of the water level statistics of Yilong Lake during the investigation.

\subsection{Sampling Method}

The effect of WLF on the growth characteristics and community structure of submerged macrophytes was studied in 16 sampling stations distributed evenly throughout the lake (Figure 2). Aquatic plants in each station were sampled monthly in low water level (August 2013 to June 2014) and high water level (July 2014 to August 2015) periods. The Braun-Blanquet approach was applied as the standard sampling procedure, with a $1 \mathrm{~m}^{2}$ sampling area and 10 parallel groups in each sampling station. The aboveground parts of aquatic plants were collected by a grass collector [23] and washed with pure water; the number of species, biomass, coverage, plant length, and branches were counted. The effect of WLF on the succession of aquatic plant community structure was monitored twice, once in a low water level period (March 2014) and again in a high water level period (March 2015). Aquatic plant sampling and monitoring procedures were carried out for the entire lake using a boat, and the species and distribution of aquatic plants were recorded to map the land covers. Figure 2 shows the round-lake route, with a sampling station shown every $100 \mathrm{~m}$ and the GPS coordinates of the sampling stations recorded. 


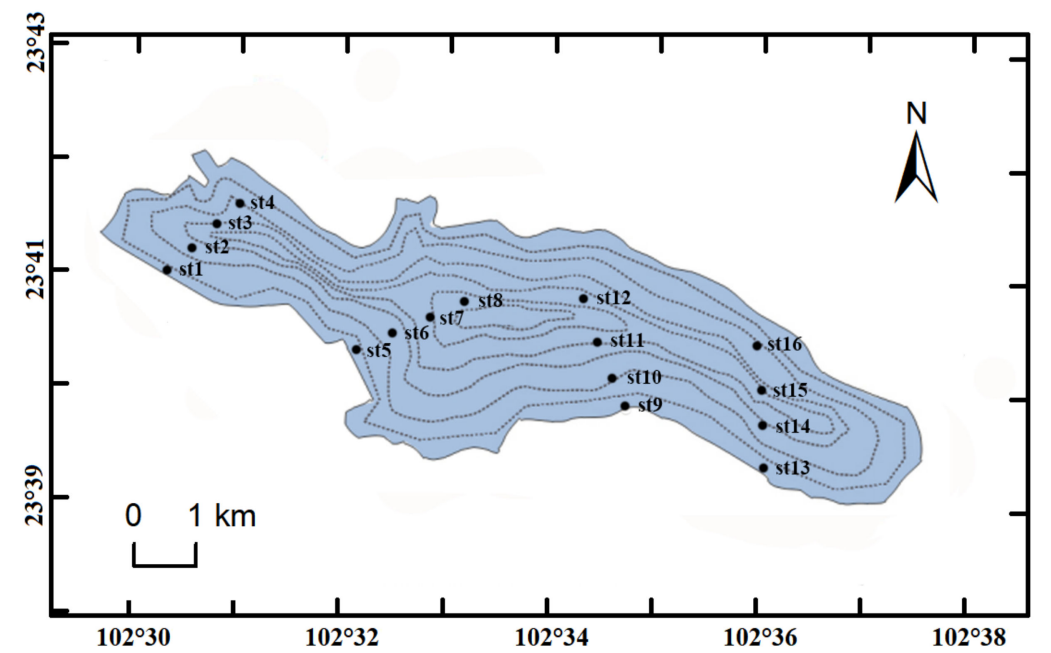

Figure 2. The distribution of sampling sites in Yilong Lake.

\subsection{Data Analysis}

The statistical analysis and graph plotting were performed using SPSS 19.0 and Origin 8.0. All data were tested for normality and homogeneity before analyses. Significant difference analyses with the plant length, biomass, branch number, coverage, and species number of submerged plants were conducted in high and low water levels (the ANOVA method with a significance level of 0.05). The ArcGIS (Version 10.5) was applied to produce a distribution map of aquatic plants.

\section{Results}

\subsection{The Effect of WLF on Growth Characteristics and Community Structure of Submerged} Macrophytes in Yilong Lake

3.1.1. The Influence of WLF on the Species and Coverage of Submerged Macrophytes

As illustrated in Figure 3, four nearshore shallow water stations (St1, St5, St9, and St13) experienced a substantial rise in species numbers $(p<0.05)$, while other sites saw a decline to varying degrees. The East and West Lakes showed different patterns, with the West Lake having a slightly decreased species number and the East Lake having a significant reduction $(p<0.05)$. In the shallow water of the West Lake, Myriophyllum spicatum and Stuckenia specinata appeared at many sampling points, but Najas marina growing in the East Lake area was significantly reduced. The difference is attributed to the increasing transparency of West Lake and decreased inhibition of submerged macrophytes by rising water levels. Furthermore, coverage is a crucial indicator for measuring the growth of submerged macrophytes. The coverage of four sampling stations (St1, St5, St9, and St13) in shallow water with high transparency increased $(p>0.05)$, while coverage of the remaining 12 stations decreased to varying degrees. Based on the location distribution of the sampling stations, the West Lake's coverage declined by significantly less than that of the East Lake, which was caused by the large-scale reduction in Najas marina in the East Lake area. From a water depth perspective, the results indicate that as water depth increases, coverage declines more rapidly. In general, the transparency of the West Lake area was high, and the inhibition effect of WLF on submerged macrophytes was not significant. However, due to the low transparency in the East Lake, the inhibition effect of WLF on species numbers and coverage was significant. Specifically, in the low water level period, the depth of the shallow area is only $40 \mathrm{~cm}$; thus, when the water level increased, the water depth was suitable in areas with high transparency, and the coverage and species numbers of the submerged macrophytes increased at several stations, including St1, St5, St9, and St13 on the lake's south bank. In contrast, due to the low transparency of the lake's north bank, the species number and coverage decreased in different ranges, indicating that when the water level increased, a proper water depth was established in places with high transparency. 


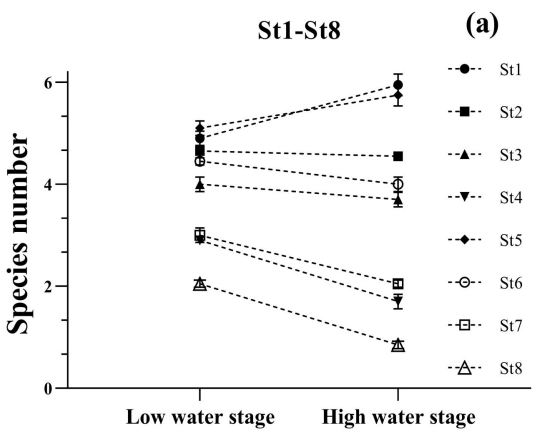

Water level

St1-St8

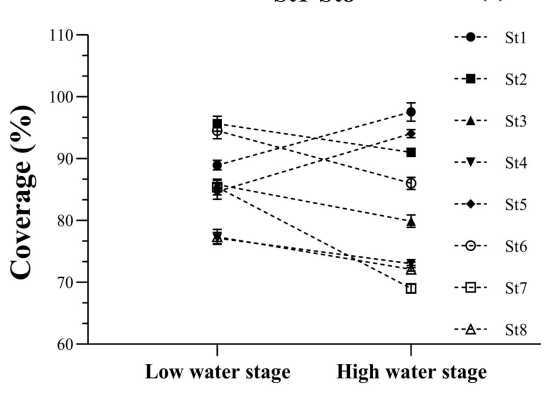

Water level

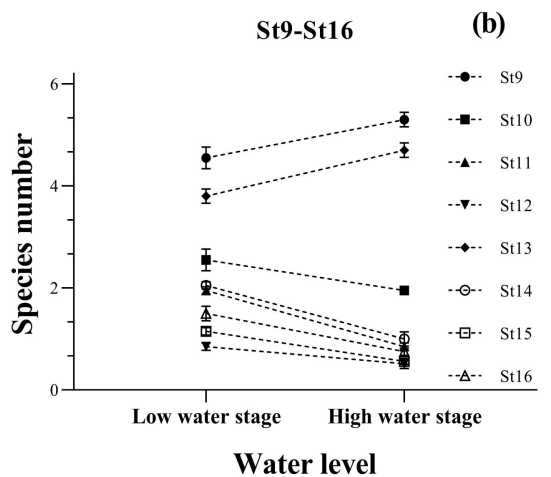

St9-St16

(d)

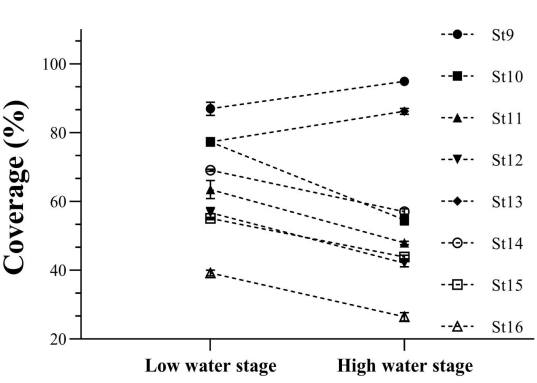

Water level

Figure 3. The species and coverage of submerged macrophytes at different water levels. (a) St1-St8 Species number; (b) St9-St16 Species number; (c) St1-St8 Coverage; (d) St9-St16 Coverage.

\subsubsection{The Influence of WLF on the Growth Characteristics of Submerged Macrophytes}

Water level has a strong driving effect on the plant length of submerged macrophytes and has a considerable inhibitory effect on branch number (Figure 4). The plant lengths of five submerged macrophytes increased by varied degrees when the water level increased. The plant lengths of Utricularia vulgaris and Najas minor grew less $(p>0.05)$, while the plant lengths of Najas marina, Myriophyllum spicatum, and Stuckenia pectinata grew significantly $(p<0.05)$. The plant length of Stuckenia pectinata increased from $95.2 \mathrm{~cm}$ to $152 \mathrm{~cm}$; that of Myriophyllum spicatum increased from $81.3 \mathrm{~cm}$ to $93.5 \mathrm{~cm}$; and that of Najas marina increased from $48.2 \mathrm{~cm}$ to $89.2 \mathrm{~cm}$. The branch number of five submerged macrophytes decreased as water level rose, which is in contrast with the trend in plant length. Because the branches of Najas minor and Utricularia vulgaris are better adapted to surviving in shallow water, their branch numbers decreased especially dramatically $(p<0.05)$. In contrast, the branch numbers of Najas marina, Myriophyllum spicatum, and Stuckenia pectinata fell insignificantly ( $p>0.05$ ); that of Najas minor decreased from 13.4 to 6.8, and that of Myriophyllum spicatum decreased from 5.9 to 5.4. The biomass of submerged macrophytes decreased after the water level increased, and the amount of biomass was reduced more in deeper waters. Overall, the East Lake's biomass loss was substantially higher than that of the West Lake $(p<0.05)$. The decrease in biomass indicates that WLF restricts the growth of submerged macrophytes and that submerged macrophytes adapt to their new habitat by reducing the number of branches and by increasing plant length as the water level rises. 

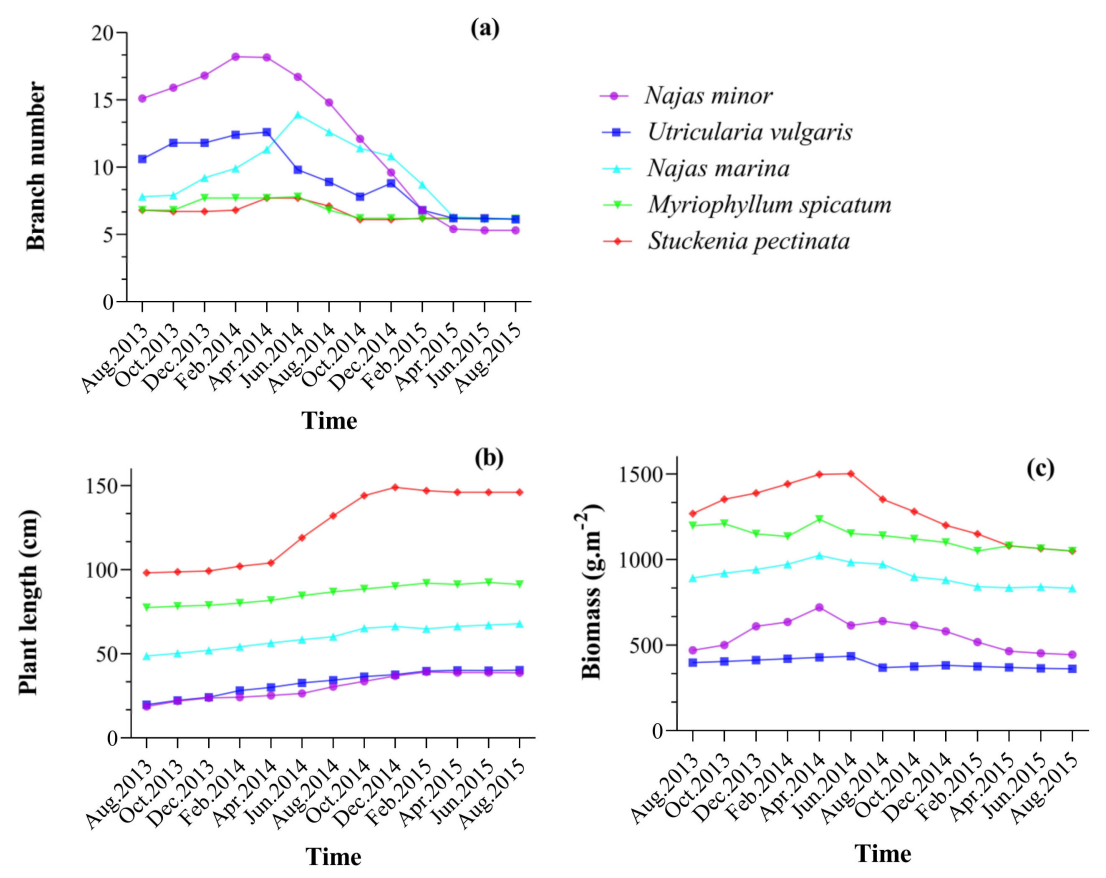

Figure 4. The influence of water level fluctuation on the growth characteristics of submerged macrophytes: (a) branch number; (b) plant length; (c) biomass (low water level before June 2014 and high water level after June 2014).

\subsection{The Influence of WLF on the Succession of Submerged Macrophytes}

According to the coverage of submerged macrophytes and emergent plants during high and low water levels, water level played a critical role in the succession of aquatic plant communities in Yilong Lake (Figure 5). The average coverage of submerged macrophytes was approximately $80.25 \%$ in low water levels and $60.85 \%$ in high water levels $(p<0.05)$. The increase in water level had no significant effect on the emergent plants $(p>0.05)$, and their average coverage decreased from $20.13 \%$ to $17.5 \%$. The coverage of submerged plants was relatively high during the low water level period, with 12 sampling stations ranging from $56.3 \%$ to $98.2 \%$, while the coverage of submerged macrophytes at six sampling stations ranged from $20.3 \%$ to $48.1 \%$ during high water level periods, indicating that the coverage decreased as the water level increased. Moreover, the coverage of emergent plants had the same changing trend, but the effect of WLF on the community was not significant. The effect of water levels on emergent plant communities mainly distributed in shallow water was not significant, while submerged macrophytes that were sensitive to water depth and transparency were impacted significantly. Overall, WLF promoted the spatial distribution of submerged macrophytes and emergent plants in the lake and then triggered the succession of aquatic plant communities in the whole lake.

Despite the fact that the coverage of submerged plants and emergent plants decreased as the water level increased, the plant distribution map (Figure 6) shows that submerged plants occupied the living space of original emergent plants after the increase in water level, resulting in the overall migration of submerged plant and emergent plant communities to the lakeshore zone. As the water depth gradient increased in the West Lake, the former suitable stand areas of Najas minor and Utricularia vulgaris gradually became Stuckenia pectinata and Myriophyllum spicatum communities. Furthermore, as a result of rising water levels in the East Lake, the low transparency also resulted in an increase in the lake bottom desertification area. 


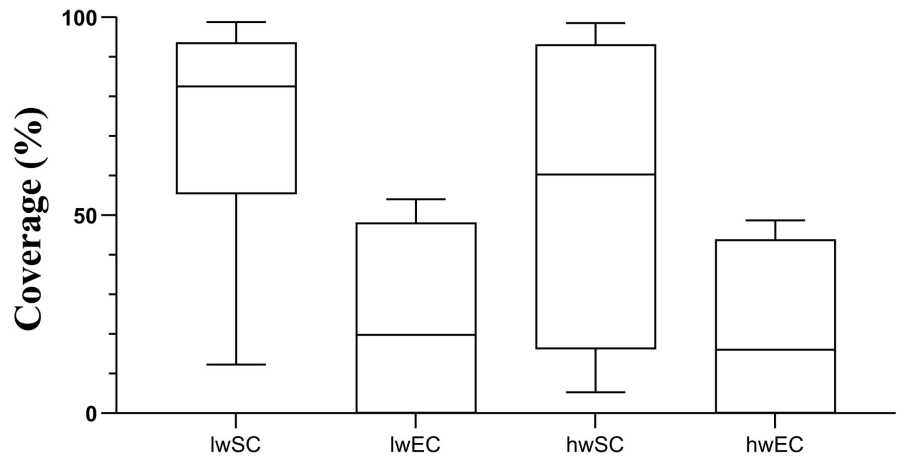

Water level

Figure 5. The influence of water level on the succession of submerged and emergent macrophytes. lwSC stands for low water level submerged macrophyte coverage; lwEC stands for low water level emergent plant coverage; hwSC stands for high water level submerged macrophyte coverage; hwEC stands for high water level emergent plant coverage.
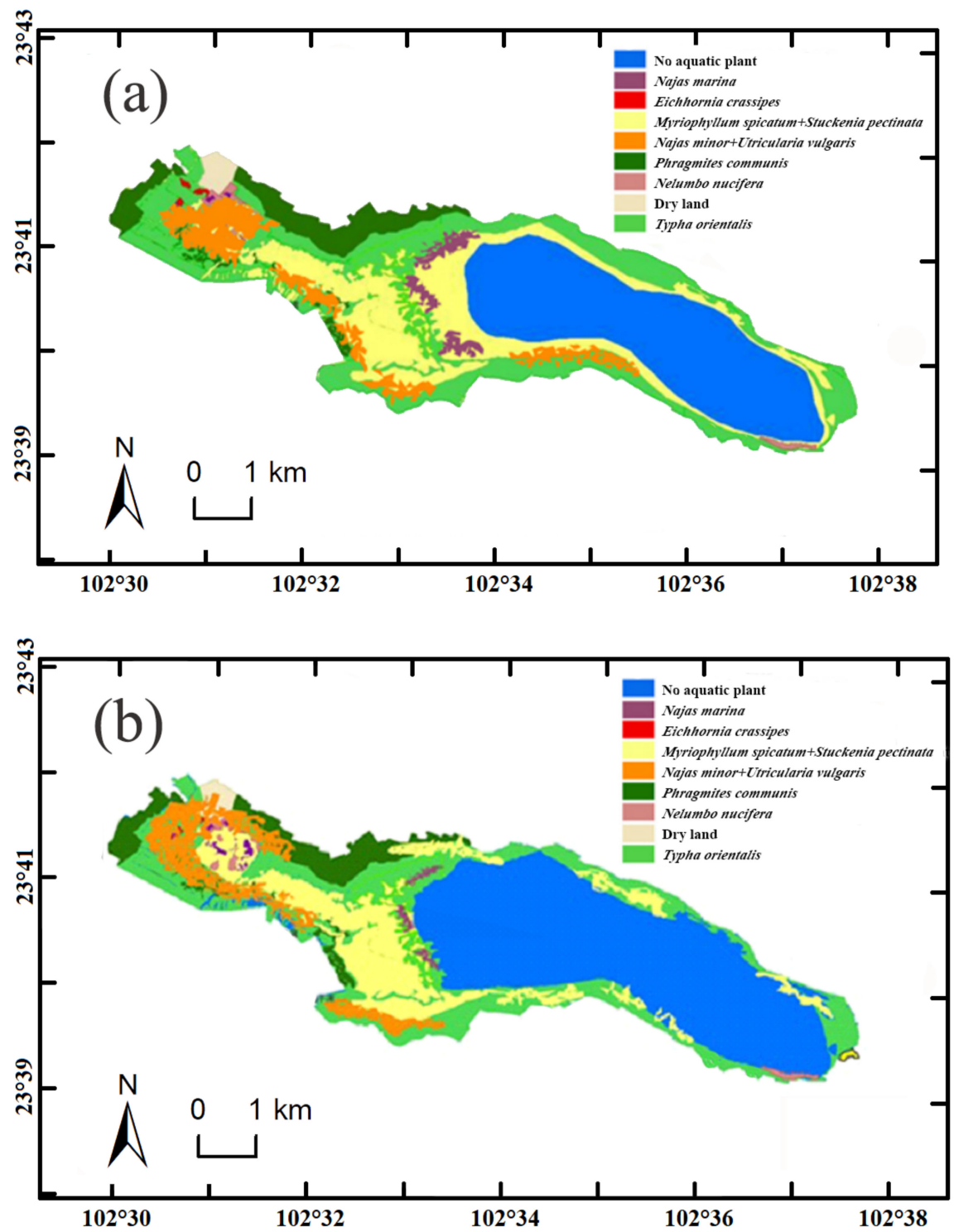

Figure 6. The distribution of aquatic plants during low water level and high water level periods in Yilong Lake. (a) The distribution of aquatic plants during low water level periods (March 2014); (b) the distribution of aquatic plants during high water level periods (March 2015). 


\section{Discussion}

WLF is a crucial hydrological phenomenon in natural waters. It is also a significant ecological component impacting aquatic plant growth, reproduction, species diversity, and community organization [24-26]. In the long-term process of natural evolution, aquatic plants have formed a series of self-regulation mechanisms to adapt to the changing water environment. Many studies have shown that WLF is one of the main driving forces for the spatial distribution of aquatic plants, primary productivity, community composition, species richness [27-29], and biodiversity [30]. However, the majority of studies have focused on the effects of WLF on a specific type of submerged macrophyte via laboratory or small-scale simulation experiments, with few focusing on the implications for the community structure succession across the entire lake. The effect of WLF on the community of submerged plants in plateau lakes is still a rarity in studies. As a vital plateau freshwater lake in China, research on aquatic plants in Yilong Lake has been sparse since 1980, and this paper is expected to provide valuable research data. The study results show that WLF has a significant effect on the species numbers and coverage of submerged plants. With the rise in water level, the species numbers in other areas decreased to varying degrees, except for the shallow water of West Lake, which indicates that the increase in water depth had a significant inhibitory effect on some species of submerged plants. A large number of Najas minor and Utricularia vulgaris that initially grew in the shallow water declined after the water level rose, even though the transparency of the area could still provide sufficient light conditions for these aquatic plants. Due to the high transparency of the West Lake coastal zone (water depth less than $40 \mathrm{~cm}$ ), the seed bank in the sediment was able to germinate after the water level rose [31], resulting in a considerable rise in the species number of the submerged plants. However, even with the same water depth, species numbers continued to decline in the East Lake, due to insufficient transparency. This suggests that we can use the method of controlling water levels to activate the seed bank in order to realize the community restoration of submerged plants [32].

Coverage is an essential indicator of a submerged plant community. With an elevation in water level, the coverage of submerged macrophytes for the entire lake showed the same trend as for species numbers. The coverage increased at four monitoring stations in the shallow water of West Lake, and it was decreased at the other sampling stations. This was mainly caused by submerged plants adjusting their growth posture and parts of submerged plants decaying under the stress of low water levels. Water depth is the primary factor in determining the species numbers and coverage. At the same time, the available light energy underwater is an important factor in determining the growth, reproduction, and community structure of submerged plants [33]. Transparency determines the intensity of the light available underwater. According to the response of submerged plant communities to WLF in the East and West Lakes, transparency is the second most important factor that affects the growth and distribution of submerged plants.

Although growth is generally inhibited, most submerged plants can germinate and grow when the water level is at an inappropriate level, because they can adapt their growth posture, material distribution, and enzyme activity to the new environment. Myriophyllum spicatum and Stuckenia pectinata usually receive more light by rapidly booming, increasing their plant length to adapt to the high water level [30]. In this study, as the water level rose, the plant lengths of five submerged macrophytes grew rapidly to ensure self-survival and community stability. However, the capacity for self-adjustment is limited, and submerged macrophytes die if the environmental changes exceed their ability to respond. They can achieve an optimal growth state by growing fast in plant length to reach the water surface and to absorb more light, selectively limiting the number of branches and reducing their level of energy consumption for respiration. This is considered an effective strategy for aquatic plants to survive in low-light and harsh environmental conditions [34] and is a survival mechanism of submerged plants to resist WLF-induced environmental stress. While collecting samples, we observed a large number of Stuckenia pectinata and Myriophyllum spicatum with root rot in the deep waters of the East Lake. When compared with the 
environmental factors of West Lake at the same water depth, dissolved oxygen (Figure S5) in the bottom layer was found to be the most different environmental factor. Therefore, even if submerged plants receive sufficient light by growing in plant length, insufficient dissolved oxygen still inhibits their growth [35] and is another important factor influencing submerged macrophytes. Therefore, the change in dissolved oxygen caused by WLF is another important factor influencing submerged macrophytes. Various submerged plants adapt to different water depths [36]. When the water level exceeds the optimal livable range of submerged plants, their transport capacity for nutrients and oxygen is limited and their enzyme activity is aberrant, resulting in submerged plant growth suppression and even death $[37,38]$. In this study, although the submerged plants adapted to the new water level environment by growing in plant length, the biomass in the entire lake decreased significantly, which indicated that the fluctuation range of the water level deviated from the most suitable water level, resulting in the inhibition of growth. This is similar to the dramatic decline in biomass and density of submerged plants such as Vallisneria natans and Potamogeton wrightii caused by the 1998 Poyang Lake flood [39].

According to the response characteristics of species number, coverage, plant length, biomass, branch number, and other indicators to WLF, the key factor that inhibits the growth of submerged macrophytes in the shallow area of the East Lake is low-light conditions. In the deepwater areas of the East Lake, the key factors are low light and low dissolved oxygen. In general, WLF causes a shift in water depth, which changes the light conditions, dissolved oxygen, and other environmental parameters, influencing the growth and community stability of submerged macrophytes. As a result, monitoring changes in water depth caused by WLF becomes more critical and manageable as decision-makers employ appropriate management strategies to handle WLF issues. The effect of WLF on a multi-species submerged macrophyte community is complex, and the effect on each submerged macrophyte is different. The centrifugal organization model of species distribution proposed by Keddy [40] is based on the belief that when the species selection for water level is consistent, the species with the most appropriate water level predominates in the center and other species are arranged in gradient. Thus, a new competitive relationship emerges among submerged plant species, changing the initial competitive balance and promoting the emergence of new dominating species. In contrast, other submerged plant species experienced declines or even extinctions as a result of such a competitive pressure. In our study, Myriophyllum spicatum, Stuckenia pectinata, and Najas marina adapted to WLF by rapidly growing in plant length as the water level increased and transparency reduced. However, submerged macrophytes such as Najas minor and Utricularia vulgaris are unable to rapidly grow in plant length, putting them at a disadvantage in the new species competition environment. Furthermore, because submerged plants such as Myriophyllum spicatum rapidly occupied the upper layers of the water, a shortage of light was present in the bottom layer, giving plants an advantage in the competition. The submerged macrophytes in the bottom layer were inhibited or partially died, resulting in a reduction in species number, biomass, and coverage. WLF can be seen to have an influence on the submerged macrophyte community via adaptive adjustment and interspecific competition. To determine the range of WLF for future protection of submerged plants, management decisions on WLF should take into account the target submerged plant's competitiveness and self-regulation capacities.

The distribution of aquatic plant communities indicates that WLF has a significant impact on the aquatic plant community in Yilong Lake. Emergent plants such as Phragmites communis and Typha orientalis were the main dominant species in shallow waters at low water levels. When water levels rose, the growth and diffusion of plant communities were inhibited in their original areas [41,42], and they moved upward along the water's shoreline to meet increasing demands for light and water depth. The reduction in biomass and density of Phragmites communis and other emergent plants under high water levels creates the primary conditions for germination of the submerged macrophyte seed bank [43], resulting in a significant increase in the species numbers of submerged macrophytes in 
shallow water. An analysis of the data from all sampling stations indicated that the declining number of submerged macrophyte species in the deepwater area was a result of rising water levels and the fact that plants not tolerant of deep waters (such as Najas minor and Utricularia vulgaris) became extinct, that Myriophyllum spicatum and Stuckenia pectinata became new dominant species, and that Najas marina spread into the transitional zone. Before the water level rose, Najas minor and Utricularia vulgaris were the dominant species in the shallow waters. With the water level increase, Najas marina and Myriophyllum spicatum became companion species, and a succession of Myriophyllum spicatum and Najas marina to the original shallow water was promoted by WLF, which led to an increase in the biodiversity of submerged macrophytes. Geest [44] found that appropriate WLF is favorable in boosting biodiversity, in a study of 215 lakes in the Netherlands. After researching 21 lakes in New Zealand, Riis [45] found that WLF close to $1 \mathrm{~m}$ is most conducive to promoting species diversity; however, our study does not support this conclusion. When considering the most suitable WLF, decision-makers should consider the water transparency, dissolved oxygen, and specific submerged macrophyte species. In this study, WLF promoted the overall area of aquatic plant distribution, but the total biomass of submerged plants was reduced, which indicated that the artificial regulation of water levels was contrary to the original purpose of submerged plant restoration.

\section{Conclusions}

To study the effect of WLF on the community structure of submerged plants, the WLF and submerged plants in Yilong Lake were monitored over two years. According to the obtained results, several conclusions can be drawn:

1. WLF has a significant effect on the submerged macrophyte community in Yilong Lake. Submerged macrophyte species numbers, biomass, and coverage all respond to the WLF to varying degrees. The species numbers, biomass, and coverage of submerged plants decreased as water level increased in deep and shallow water areas with low transparency. However, the species numbers increased in the shallow water area with high transparency, indicating that controlling the WLF range could be used to activate seed banks in lakes with abundant submerged plant seed banks in order to restore a submerged plant community.

2. Changes in water environment factors drive the succession of submerged macrophyte communities, and competition among species in the new environment is also an essential factor in promoting submerged macrophyte community succession. The increase in water level has inhibitory impacts on Najas minor and Utricularia vulgaris, while Myriophyllum spicatum, Stuckenia pectinata, and Najas marina are more adaptable to increased water levels.

3. The most suitable range of WLF is determined by the water depth, transparency, dissolved oxygen, species of submerged macrophytes, and other environmental factors which are directly changed by changing water depth. Therefore, paying attention to the change in water depth is a more direct and effective management method in the management of WLF.

4. WLF reshaped the spatial distribution of aquatic plant communities in Yilong Lake and relocated submerged macrophytes to deeper waters. The growth density of emergent plant communities in the original growth area decreased, and a proper transparent environment was created among emergent plants, which created conditions for the germination of a submerged plant seed bank. This could be a pioneering technology for the restoration of submerged plant communities in eutrophic lakes.

Supplementary Materials: The following are available online at https://www.mdpi.com/article/10 .3390/w13202900/s1, Figure S1: Water depth of Yilong lake during low water level period, Figure S2: Water depth of Yilong lake during high water level period, Figure S3: The dividing line between the East and west of Yilong Lake, Figure S4: Water transparency during the study period, Figure S5: Dissolved oxygen during the study period. 
Author Contributions: Conceptualization, F.Z. and X.C.; data curation, F.Z. and Z.Z.; formal analysis, F.Z. and X.F.; funding acquisition, X.C.; investigation, F.Z.; methodology, F.Z. and X.F.; software, X.F.; supervision, X.F. and X.C.; writing—original draft, F.Z. and X.F.; writing—review and editing, F.Z. and X.F.; F.Z. and X.F. contributed equally. All authors have read and agreed to the published version of the manuscript.

Funding: This study was financially supported by the Ministry of Science and Technology of P.R. China (grant number 2017ZX07202002-05) and the scientific research by the Science and Technology Committee of Shanghai (grant number 18DZ1206505).

Institutional Review Board Statement: Not applicable.

Informed Consent Statement: Not applicable.

Data Availability Statement: The data presented in this study are available from the corresponding author upon request.

Conflicts of Interest: The authors declare no conflict of interest. The funders had no role in the design of the study; in the collection, analyses, or interpretation of data; in the writing of the manuscript; or in the decision to publish the results.

\section{References}

1. Klimesova, J.; Klimes, L. Resprouting of herbs in disturbed habitats: Is it adequately described by Bellingham-Sparrow's model? Oikos 2003, 103, 225-229. [CrossRef]

2. Peintinger, M.; Prati, D.; Winkler, E. Water level fluctuations and dynamics of amphibious plants at Lake Constance: Long-term study and simulation. Perspect. Plant. Ecol. Evol. Syst. 2007, 8, 179-196. [CrossRef]

3. Lenssen, J.P.M.; De Kroon, H. Abiotic constraints at the upper boundaries of two Rumex species on a freshwater flooding gradient. J. Ecol. 2005, 93, 138-147. [CrossRef]

4. Belote, R.T.; Jones, R.H.; Wieboldt, T.F. Compositional stability and diversity of vascular plant communities following logging disturbance in Appalachian forests. Ecol. Appl. 2012, 22, 502-516. [CrossRef] [PubMed]

5. Voesenek, L.A.C.J.; Bailey-Serres, J. Flood adaptive traits and processes: An overview. New Phytol. 2015, 206, 57-73. [CrossRef] [PubMed]

6. Radford, I.J. Fluctuating resources, disturbance and plant strategies: Diverse mechanisms underlying plant invasions. J. Arid Land 2013, 5, 284-297. [CrossRef]

7. Sasidharan, R.; Hartman, S.; Liu, Z.; Martopawiro, S.; Sajeev, N.; van Veen, H.; Yeung, E.; Voeseneka, L.A.C.J. Signal Dynamics and Interactions during Flooding Stress. Plant. Physiol. 2018, 176, 1106-1117. [CrossRef] [PubMed]

8. Nikora, V. Hydrodynamics of aquatic ecosystems: An interface between ecology, biomechanics and environmental fluid mechanics. River Res. Appl. 2010, 26, 367-384. [CrossRef]

9. Wilcox, D.A.; Nichols, S.J. The effects of water-level fluctuations on vegetation in a Lake Huron wetland. Wetlands 2008, 28, 487-501. [CrossRef]

10. Li, N.; Yang, L.; Deng, X.; Wang, Z.; Li, Z. Aquatic plant diversity in relation to lake morphology in the middle and lower reaches of the Yangtze River. Plant. Sci. J. 2018, 36, 65-72. [CrossRef]

11. Luo, F.; Matsubara, S.; Chen, Y.; Wei, G.; Dong, B.; Zhang, M.; Yu, F. Consecutive submergence and de-submergence both impede growth of a riparian plant during water level fluctuations with different frequencies. Environ. Exp. Bot. 2018, 155, 641-649. [CrossRef]

12. Liu, L.; Guan, Y.; Qin, T.; Wang, Y.; Li, H.; Zhi, Y. Effects of water regime on the growth of the submerged macrophyte Ceratophyllum demersum at different densities. J. Freshw. Ecol. 2018, 33, 45-56. [CrossRef]

13. Zhou, N.; Hu, W.; Deng, J.; Zhu, J.; Xu, W.; Liu, X. The effects of water depth on the growth and reproduction of Potamogeton crispus in an in situ experiment. J. Plant. Ecol. 2017, 10, 546-558. [CrossRef]

14. Emenyonu, C.A.; Eze, C.C.; Ejike, O.U. Factors influencing Cassava Farmers' Climate Change Risk Perception in Anambra State, Nigeria. Am. J. Clim. Chang. 2020, 9, 217-227. [CrossRef]

15. McGowan, S.; Leavitt, P.R.; Hall, R.I.; Wolfe, B.B.; Edwards, T.W.D.; Karst-Riddoch, T.; Vardy, S.R. Interdecadal declines in flood frequency increase primary production in lakes of a northern river delta. Glob. Chang. Biol. 2011, 17, 1212-1224. [CrossRef]

16. Yao, X.; Yang, G.; Wan, R.; Wang, X. Impact of water level change on wetland vegetation of rivers and lakes. J. Lake Sci. 2014, 26, 813-821. [CrossRef]

17. Maxwell, P.S.; Pitt, K.A.; Burfeind, D.D.; Olds, A.D.; Babcock, R.C.; Connolly, R.M. Phenotypic plasticity promotes persistence following severe events: Physiological and morphological responses of seagrass to flooding. J. Ecol. 2014, 102, 54-64. [CrossRef]

18. Li, B.; Tan, W.; Wen, L.; Zhao, X.; Peng, B.; Yang, J.; Lu, C.; Wang, Y.; Lei, G. Anthropogenic habitat alternation significantly decreases $\alpha$ - and $\beta$-diversity of benthopelagic metacommunity in a large floodplain lake. Hydrobiologia 2020, 847, $293-307$. [CrossRef] 
19. Barbosa, V.V.; Severiano, J.d.S.; de Oliveira, D.A.; de Lucena Barbosa, J.E. Influence of submerged macrophytes on phosphorus in a eutrophic reservoir in a semiarid region. J. Limnol. 2020, 79, 138-150. [CrossRef]

20. Li, L.; Bonser, S.P.; Lan, Z.; Xu, L.; Chen, J.; Song, Z. Water depth affects reproductive allocation and reproductive allometry in the submerged macrophyte Vallisneria natans. Sci. Rep. 2017, 7, 16842. [CrossRef]

21. Zhao, F.; Zhang, W.; Liu, Y.; Wang, L. Responses of growth and photosynthetic fluorescent characteristics in Ottelia acuminata to a water depth gradient. J. Freshw. Ecol. 2018, 33, 285-297. [CrossRef]

22. Coops, H.; Beklioglu, M.; Crisman, T.L. The role of water-level fluctuations in shallow lake ecosystems-Workshop conclusions. Hydrobiologia 2003, 506, 23-27. [CrossRef]

23. Zhang, M.; Ni, L.; Xu, J.; He, L.; Fu, H.; Liu, Z. Annual dynamics of the wetland plants community in Poyang Lake in response to water-level variations. Res. Environ. Sci. 2013, 26, 1057-1063.

24. Hargeby, A.; Blindow, I.; Hansson, L.A. Shifts between clear and turbid states in a shallow lake: Multi-causal stress from climate, nutrients and biotic interactions. Arch. Hydrobiol. 2004, 161, 433-454. [CrossRef]

25. Havens, K.E. Submerged aquatic vegetation correlations with depth and light attenuating materials in a shallow subtropical lake. Hydrobiologia 2003, 493, 173-186. [CrossRef]

26. Van Geest, G.J.; Roozen, F.; Coops, H.; Roijackers, R.M.M.; Buijse, A.D.; Peeters, E.; Scheffer, M. Vegetation abundance in lowland flood plan lakes determined by surface area, age and connectivity. Freshw. Biol. 2003, 48, 440-454. [CrossRef]

27. McMahon, T.A.; Finlayson, B.L. Droughts and anti-droughts: The low flow hydrology of Australian rivers. Freshw. Biol. 2003, 48, 1147-1160. [CrossRef]

28. Keddy, P.A.; Reznicek, A.A. Great Lakes Vegetation Dynamics: The Role of Fluctuating Water Levels and Buried Seeds. J. Gt. Lakes Res. 1986, 12, 25-36. [CrossRef]

29. Strange, E.F.; Hill, J.M.; Coetzee, J.A. Evidence for a new regime shift between floating and submerged invasive plant dominance in South Africa. Hydrobiologia 2018, 817, 349-362. [CrossRef]

30. Zhu, G.; Hu, P.; Liu, X. Effect of lake hydrodynamic on distribution of aquatic plants. Acta Ecol. Sin. 2019, 39, 235-243. [CrossRef]

31. Thompson, K.; Grime, J.P. Seasonal variation in the seed banks of herbaceous species in 10 contrasting habitats. J. Ecol. 1979, 67, 893-921. [CrossRef]

32. Ye, C.; Wu, G.; Zhao, S.; Wang, S.; Liu, Y. Drought response and influencing factors of wetland vegetation in Poyang lake national nature reserve. J. Lake Sci. 2014, 26, 253-259. [CrossRef]

33. Heidbuechel, P.; Jahns, P.; Hussner, A. Chlorophyll fluorometry sheds light on the role of desiccation resistance for vegetative overland dispersal of aquatic plants. Freshw. Biol. 2019, 64, 1401-1415. [CrossRef]

34. Zhou, J.; Wang, D. Effects of flooding depth, duration and frequency on the early growth of Myriophyllum spicatum in Yangtze River. Acta Hydrobiol. Sin. 2012, 36, 939-945. [CrossRef]

35. Yang, X.; Sun, S.; Bo, X.; Zhang, Q.; Chen, K. Influences of water depth gradient on photosynthetic fluorescence characteristics of Vallisneria natans. J. Lake Sci. 2014, 26, 879-886. [CrossRef]

36. Ji, G.; Xu, H.; Wang, L.; Zhao, F. Effect of light intensity of different water layers on the growth of four submerged macrophytes. Environ. Pollut. Control 2011, 10, 29-32. [CrossRef]

37. White, S.D.; Ganf, G.G. The influence of convective flow on rhizome length in Typha domingensis over a water depth gradient. Aquat. Bot. 1998, 62, 57-70. [CrossRef]

38. Sorrell, B.K.; Mendelssohn, I.A.; McKee, K.L.; Woods, R.A. Ecophysiology of wetland plant roots: A modelling comparison of aeration in relation to species distribution. Ann. Bot. 2000, 86, 675-685. [CrossRef]

39. Cui, X.; Pu, Y.; Xiong, B. Effect of water depth gradient on growth and reproduction of Potamogeton wrightii morong. Acta Hydrobiol. Sin. 1999, 23, 269-272. [CrossRef]

40. Wisheu, I.C.; Keddy, P.A. Competition and centrifugal organization of plant communities: Theory and tests. J. Veg. Sci. 1992, 3, 147-156. [CrossRef]

41. Han, B.; Zhang, S.; Wang, P.; Wang, C. Effects of water flow on submerged macrophyte-biofilm systems in constructed wetlands. Sci. Rep. 2018, 8, 2650. [CrossRef]

42. Vretare, V.; Weisner, S.E.B.; Strand, J.A.; Graneli, W. Phenotypic plasticity in Phragmites australis as a functional response to water depth. Aquat. Bot. 2001, 69, 127-145. [CrossRef]

43. Johnson, O.F.; Lishawa, S.C.; Lawrence, B.A. Submerged harvest reduces invasive Typha and increases soil macronutrient availability. Plant. Soil 2019, 442, 157-167. [CrossRef]

44. Van Geest, G.J.; Coops, H.; Roijackers, R.M.M.; Buijse, A.D.; Scheffer, M. Succession of aquatic vegetation driven by reduced water-level fluctuations in floodplain lakes. J. Appl. Ecol. 2005, 42, 251-260. [CrossRef]

45. Riis, T.; Hawes, I. Relationships between water level fluctuations and vegetation diversity in shallow water of New Zealand lakes. Aquat. Bot. 2002, 74, 133-148. [CrossRef] 